\title{
Obstacles Encountered by Foreign Investors in Kosovo
}

\author{
Nakije Kida \\ $\mathrm{PhD}$ (C) European University of Tirana, Republic of Kosovo, Pristina.
}

\begin{abstract}
The purpose of the paper is finding obstacles that led to the reduction of foreign ivestitors' motive to come to Kosovo. Through the survey was taken the opinion of the sample from 306 current investors with 100\% foreign capital operating in Kosovo. Descriptive analysis has depicted the main obstacles in their business activity. Weak enforcement of law, corruption, failure to integrate into the EU, poor infrastructure, lack of financial incentives, poor business climate, highlighted poverty, frequent legal changes are part of these obstacles. However, Kosovo has the youngest workforce in Europe, well educated and who speak more than one language. Multiple natural properties make it attractive, toond. The main conclusion that can be drawn from the above findings is that Kosovo has not become fully available to all mechanisms to welcome the foreign investors. It is suggested that the government comes up with concrete projects to stimulate investors and create the necessary climate to develop their business.
\end{abstract}

Keywords: Foreign Investors in Kosovo; Obstacles encountered by investors, Surveys, Descriptive analysis.

\section{Introduction}

Kosovo, based on indicators of the economy has recently had positive growth trend despite the international financial crisis. Investments are supposed to be important growth factors in Kosovo. However, Kosovo is still not attractive for investors. Kosovo non-membership in EU is an obstacle towards a faster economic development. The fact that Kosovo is a member of the Multilateral Investment Guarantee Agency (MIGA), the legal framework in improving process, does not mean that the foreign investors as well as local ones have guaranteed the capital. Weak intermediate state links (judiciary, frequent legal changes), encourage investors to repatriate their profits. While the taxes are low, investors hesitate to pay taxes. With a default VAT scale of $16 \%$, Corporate income tax of $10 \%$ (CIT), progressive scale from 4, 8 and 10\%,on personal income tax (PIT), are very attractive to do business (Investor Guide, Investing in Kosovo, May 2011). In addition, European Free Trade agreement creates opportunities for Kosovar products to penetrate outside Europe (MTI .2012:3). Reviewing the dynamics of FDI in Kosovo in a decade and a half, we notice a positive fluctuation up to 2007. This fluctuation is usually comparable with countries in transition. Such FDI fluctuation is related to macroeconomic and financial arrangements to some extent stable, with positive economic growth in average of 4.0 percent. Given the importance of FDI as a boost export growth and productivity, their contribution to economic growth is undisputed (World Bank, 2002). With a negative balance of payments (low exports), Kosovo is not in a good position, though vital economic statistics encourage the growth of FDI.

\section{Review of the Literature}

Theoretical Review on FDI shows a strong scholarly attempt to explain that FDI are considered as a factor that promotes growth. FDI and economic growth are well studied in the economy after the introduction of endogenous growth model, originally proposed by Romer et al. (1996), and supported in advance by Boreinsztein et al. (1995:115-135) and Balasubramanyam et al (1996:16). Basically conceptual work and study framework for FDI derives strongly from studies of Boreinsztein et al (1995:9, 1998:1125), Carkovic and Levine (2002:12), Alfaro et al (2003:18). They have shown the long term effect of FDI on economic growth. Foreign direct investment (FDI) is the money invested by a company of a country in another country, in the inner structure of economy, equipment, facilities, manufacturing, distribution, marketing, research and development (R \& D), etc. A broad definition of FDI is provided by the OECD (Benchmark FDI", 1999:7), "Foreign Direct Investment according to OECD (2007), reflect the intention of providing a lasting interest of a resident entity in an economy (direct investor), a resident entity in another economy (direct investment enterprise). Lasting interest implies the existence of a long-term relationship between the direct investor and the enterprise and a significant degree of influence on the management of the enterprise." FDI come through Multinational 
Enterprises which besides the headquarters in the country of origin make diversification of subsidiaries in different countries in order to provide their capital from economic and political fluctuations that occur.

\section{Research Methodology}

This chapter uses the primary data (quantitative approach), provided through instruments (questionnaires). From the population of 1369, foreign investors have chosen the sample of 500 foreign companies with $100 \%$ foreign capital (leaving aside investors with mixed capital, according to KSA. 2014, there are 3721 in total), due to the accuracy of data in disposal of KSA (June 2014), about this group of investors. This analysis provides the opinion of foreign companies operating in Kosovo about the obstacles that the investors have faced to invest in Kosovo. Due to descriptive analysis, is achieved the testing of the hypothesis: "Obstacles encountered by foreign investors while investing in Kosovo", from structured data obtained through the survey face to face and via emails. The surveyed companies (surveys are confidential), were asked to complete the whole questionnaire. There were used 200 face to face questionnaires and 106 questionnaires were conducted through emails (for a period of 3 months, October - December 2014). Therefore the exemplar includes a total of 306 respondents (jointly developed and self-administered), with accuracy of $95.5 \%$ in the total sample of 1369 companies with $100 \%$ foreign capital in Kosovo.

\subsection{Sampling}

The study population comprises foreign investors in Kosovo. The study sample comprises foreign investors with $100 \%$ foreign capital. The sample is random, representative sample of the entire population of foreign investors with $100 \%$ foreign capital. The population in this study is 1369 Foreign Investors, enough to survey 306 foreign investors. For example, the recommended sample size for a population of 1500, a confidence level of $95.0 \%$, and a margin of error (degree of accuracy) of $5 \%$ would be 306 . The sample size calculation was based on the following considerations: For a simple random sample was assumed as follows: a sample is obtained of $\mathrm{N}=306$, [the Research Advisors (2006)], sufficient, despite the failure of 194 companies (out of the planned sample of 500 investors).

\subsection{The Content of Questionnaires}

The questionnaire includes questions concerning the recognition of the key elements of the activity of companies and the obstacles they have encountered in the exercise of their activity:

- The main type of business, year of establishment, seat location, number of employees, years of doing business in Kosovo, the realized turnover in years, the size of the investment that you have made, the ranking of business environment, what has attracted to invest, difficulties on priority basis, the most important government actions, additional comments.

\section{Descriptive analysis (Obstacles encountered by foreign investors in Kosovo)}

The questionnaire starts with reports about the business residence, where it acts and ends, with the solution of the most important actions that the Government of Kosovo should take to improve the business environment. In the survey are present foreign companies from the following countries: Germany $17 \%$, Switzerland $12 \%$, UK 8\%, Turkey 13\% Netherlands 5\% Albania 25\%, Macedonia 7\%, Slovenia 2\%, France 9\%, and Serbia 2\%.

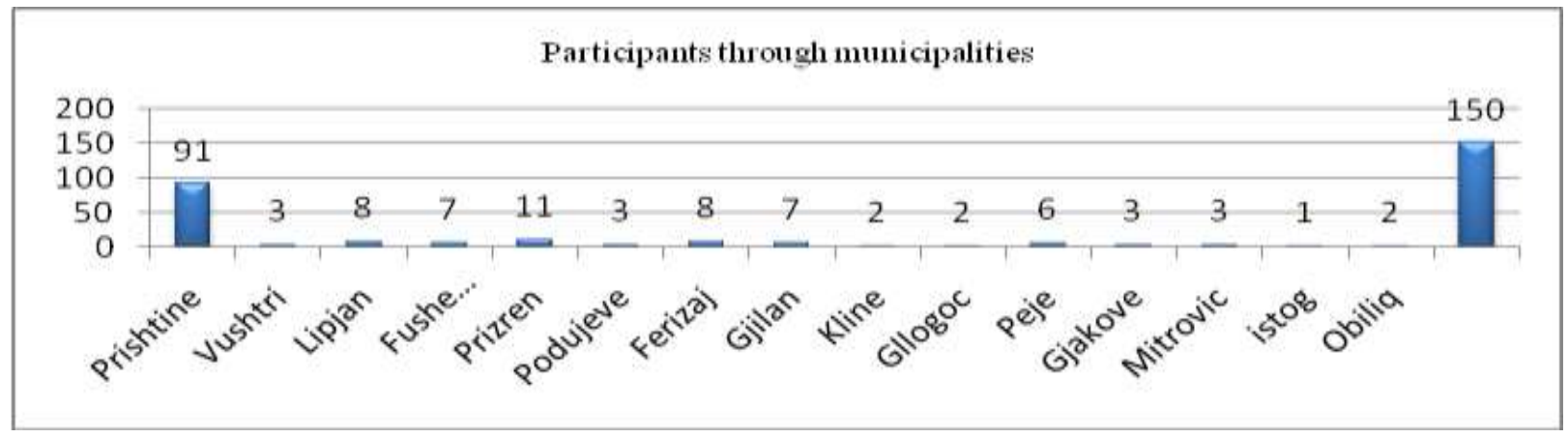

Fig. 1: Business location. 
- Location of the business, about the business headquarters, 150 companies or $49 \%$ of 306 companies surveyed did not respond (respondents require confidentiality). While most of them operate in Pristina, 91 companies or 29.7 percent, and 21.3 percent or 66 companies operate in other Kosovo towns.

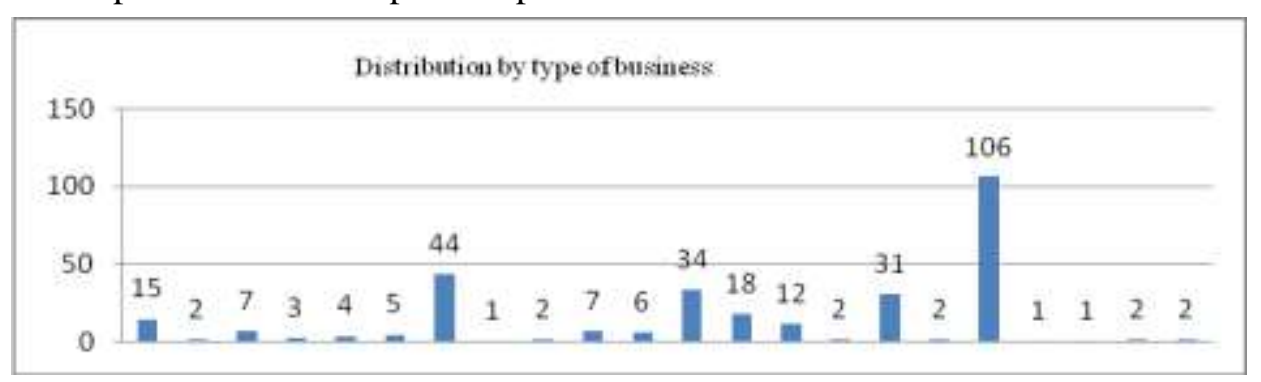

Fig. 2: Distribution by type of business.

- Distribution By type of business, if you see what activity they develop, it is clear that the majority of 106 companies or 22.5 percent of them perform more than one economic activity, being summarized in the name "other". The survey includes 304 companies (98\%) of the total 306 respondents, where, 44 companies or 14.4 percent of them are in trade, 34 companies (11\%) road construction, 31 companies or 10.1 percent are in cultural events, arts, and market surveys. Telecommunications companies are 18, or 5.9 percent, electricity and natural gas are 12 or 3.9 per cent, food industry is 7 or 29.2 percent.We have also the banking sector with 6 companies or 1.96 percent, while in textile industry, road and rail transport, tourism, hospitality, sport, health, engineering activities, advertising agencies and air transport are represented 22 companies or 7.2 per cent.

- The year of business establishment, it is estimated that in 2000 were registered 5 percent of businesses, from 2001 to 2003 were registered by $2 \%$ of companies each year, from 2004 to 2007 registered businesses were not more than 9 percent $(6 \%, 7 \%, 9 \%, 8 \%)$. The year 2008, despite the European crisis, has increased the number of companies registered at 12 percent. While the years 2009 and 2010 (15\% and 16\%), according to the survey, are considered the years with the most registered new companies in Kosovo. The trend has decreased in the following years, 2012 to 7 percent, 2 percent in 2013 and 1 percent in 2014. This negative trend of FDI inflow is very disturbing, which is confirmed by current CBK statistics (2014).

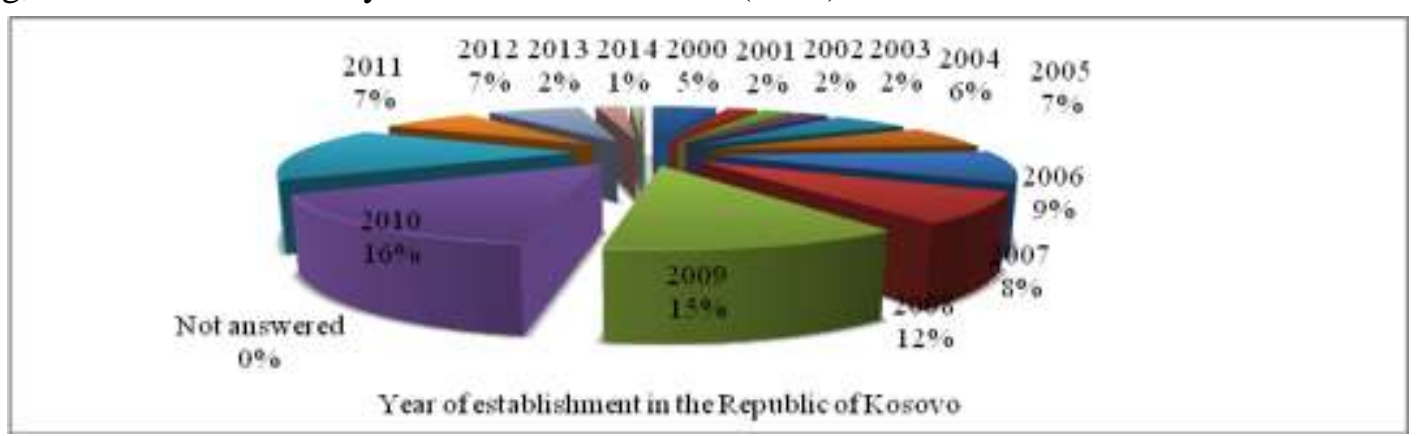

Fig. 3: Years of business establishment.

- Number of employees by years, foreign companies in the first year of establishment employed the majority of workers or 30.63 per cent of employees in total (between the minimum zero and maximum of 2000 workers), not answering only 11 respondents. In 2013 this average raises at 42.86 percent or 12.23 percent more employees, while 19 respondents did not answer. In 2014, 54 companies or 17.6 percent refused to answer, the average employment rate was 45.3 per cent or 2.44 per cent higher than a year ago, but this had been the lowest percentage since the arrival of the first companies in Kosovo. This way we come to conclusions that foreign companies do not contribute enough to employment and the level of wages is $40 \%$ percent higher than that of the local companies. While, the staff employed in the banking sector is found to have been reduced from 1700 to 1300 employees or 31 percent less in October 2014. There are businesses that do not have employees and their number is considerable. This means that some foreign companies bring technology to Kosovo but do not develop business activity, so they extinguish after 1 or 2 years (from 306 companies surveyed, 35 percent of them have extinguished their activity after 1 or 2 years).

- Years of doing business in Kosovo, from foreign businesses which operate in Kosovo according to the survey, 48 percent of them carried out up to 5 years, and 33 percent of companies from $6-10$ years. There are 9 percent 
of companies that have worked in Kosovo from 11-15 years, while 10 percent of companies have not responded. Foreign companies that operated in Kosovo did not stay long with the exception of the banking and insurance sectors which contain 9 per cent (from 11-15 years of residence in Kosovo) as a result of higher profits.

- For the year of business extinction, from 306 companies surveyed, 43 active companies in Kosovo have responded, without indicating the year they were established. 177 respodents have not answered, but as they emphasize, they have contractual agreements with Kosovar business subcontractors (construction sector), in bringing heavy machinery, and the telecommunications sector in bringing technology and expertise from 2000 to 2014. There are mainly construction companies, banks, market research, trade and tourism. From 306 companies, 76 businesses or 25 percent of them were extingushed from 2000 to 2012, where only in 2014, 18 of them or nearly 6 percent in total were extinguished.

- Ranking in doing business, is considered reasonable by 35 percent of foreign investors, as well as 35 percent of respondents. This assessment is good when we take into consideration the obstacles and difficulties that have been ranked by investors. While, 98 percent of respondents have responded the survey and only 2 percent did not respond. There were 6 per cent who ranked the business environment as poor, while 22 per cent as unreasonable, encourage policy-makers and institutions which promote investments, to make reforms in improving the business environment.

- Good opportunities for investments, in the question what made the foreign companies invest in Kosovo, are listed a number of questions with approximate answers. Asked whether Kosovo offers the best opportunities for investment, we have received encouraging response, where 46 percent of foreign investors consider Kosovo as a place that provides good opportunities to invest. There were 22 percent of investors who refused to answer, and 32 percent of them consider it as less important. The assessment that Kosovo has what to offer makes it clear that nearly half of the investors have a long term plan to stay in Kosovo. While the non-response of 22 percent of them, shows that if the government takes additional incentives (tax release for the first 6 months, financial incentive or award for free use of buildings or land for at least a year, exemption from VAT for heavy machinery in the mines, agricu., and construction, etc.).

- Ranking of Kosovo as a central location in the region is not considered as such by 44 percent of respondents, and if we add the 28 percent refused to answer then it is sufficient to know the reason why investors are casting eyes elsewhere to invest. While we consider important 28 percent of them, which implies that we must be directed to activities that promote Kosovo's image and provide foreigners with accurate and rapid information.

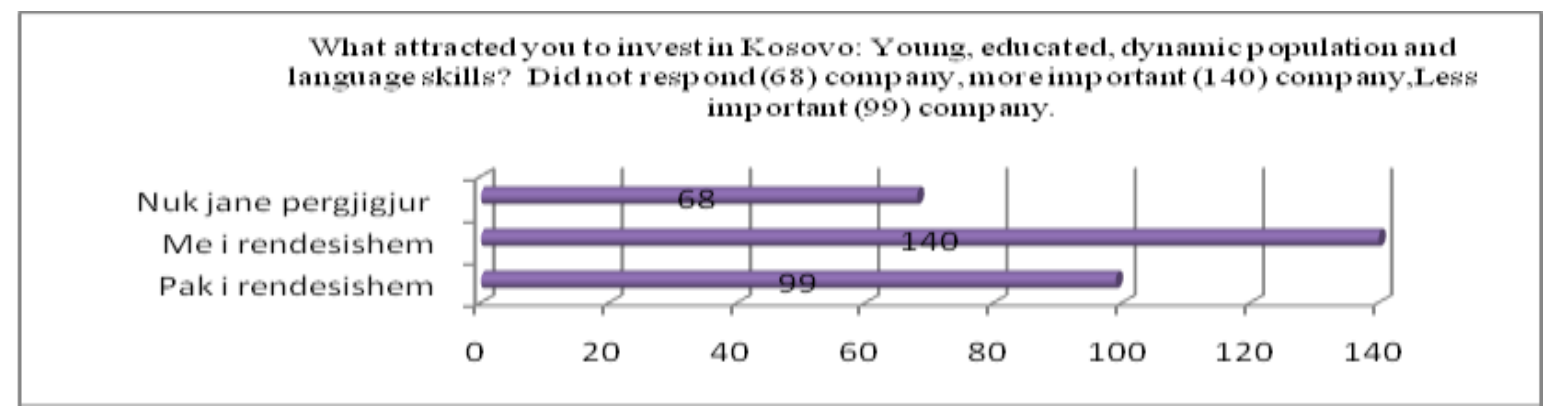

Fig. 4: Young, educated, dynamic population and language skills.

- Young, educated, dynamic population and language skills, Kosovo is internationally recognized as a country with a dynamic population, average educational attainment and with the youngest population in Europe. These factors make it very attractive to 140 companies or about 46 percent of investors, while 99 companies or 32.35 per cent of the them consider it less important. Of 306 respondents surveyed, 68 companies or 22.2 percent of them did not answer.

- Competitive, well qualified and low cost labor force (figure 10), being competitive with neighboring countries for skilled labor force and low cost is very challenging for the country that claims to attract investors with such a pattern. Kosovo stands better than all neighboring countries except Albania, which is competing in the region. The opinion of 51 percent of investors confirms that Kosovo offers cheap labor force and a sufficient level of education to use work technology. Less significant is considered by 30 percent of respondents, while 19 percent of them hesitated to answer. 
- Modern Telecommunications, Kosovo has advanced strongly in this direction, especially after 2007, with the infrastructure of telecommunications and has constantly been improving it. From the response of investors there comes not a good opinion, where 151 companies or 49.3 percent consider these factors as less important, while 75 companies or 24.5 percent consider these as important factors, and 81 companies or 26.5 percent did not respond.

- Modern and compatible legislation with the EU, another characteristic is the modern and compatible legislation with that of EU, providing an ease in knowing the law and procedures. Modern legislation, compatible with the $\mathrm{EU}$, is an even greater security on the invested capital in Kosovo. There are 77.1 percent of investors who answered. From them 94 companies or 39.4 percent of them see it as important, while 143 company rank it as less important. The are 70 companies or 22.9 percent that did not respond.

- The responsible banking system, is an opinion that does not support although the banking system is liquid and very profitable for the investors who have invested. Investors of other sectors, 47 percent of them, consider the banking system less important, and 28 percent of them did not answer. So, a response of over 75 is too high. Only 25 percent of investors consider the banking system important.

- Free Access to the EU market, is considered important by 26 percent of respondents. While 49 per cent of foreign companies consider it as less important, and 25 percent of them did not respond. Since the majority of investors come from the EU countries, it is clear that investors do not face trade barriers while investing in Kosovo, so they do not give much importance to this factor.

- Tax Incentives, are considered as insufficient by the foreign investors despite the fact that Kosovo has the lowest tax rates in the region. Income tax rate of 10 percent in Corporates is competitive in the region, and Individual Income with progressive degree of 4, 8 and 10 percent, with standard VAT rate of 16 percent. However there are insufficient customs tariffs incentives and tax exemptions for new and successful businesses. In the survey, 26 percent of companies did not answer, and 35 percent of companies consider tax incentives as less important. Satisfied with tax incentives are 39 percent of respondents who consider Kosovo desirable to invest but they consider frequent and continuous legislative changes obstacles to plan the invested capital and their possible benefits. New fiscal reforms are expected by July 2015.

- Corruption and nepotism, Kosovo as most of the countries in the Balcans is going through a difficult transition period. Kosovo development path is hindered by the negative phenomena in society, such as corruption and nepotism. From the opinion of foreign companies it is clear that this is a serious drawback of Kosovo society. Of 306 companies surveyed, 198 of them or 65 percent have encountered corrupt people in contact with governmental and municipal institutions (the state officials). As the most corrupt they consider customs, judiciary, inspectorates in the Ministry of Commerce, Industry, procurement, taxes, Kosovo Police Service. At least once each company has faced corruption barrier during business procedures in relation to the state. They also do not hesitate to declare (require confidentiality), that do not like to pay taxes, often considering the reasons for closing companies within 1-2 years and opening of new companies. Companies that do not consider corruption and nepotism a major obstacle are 74 or 24 percent of them. There are 34 companies which did not respond to the survey, or 11 percent of them. They see this as a lack of willingness to report these occurrences to society even though the mechanisms for combating these negative phenomena exist.

- Bureaucratic procedures are considered the biggest obstacle, reported by 198 companies or 64.7 percent of them. As less difficult they are considered by 73 companies or 23.8 percent, whereas 36 companies or 11.7 percent of them did not respond.

- Infrastructure and physical environment, is considered as an obstacle by 96 companies or 31.4 percent of them, while less difficult by 155 companies or 51 percent of them. There are 56 companies that did not respond or 17.6 percent. As infrastructure they consider roads, telecommunications, energy and water supply. Mostly they emphasize that major obstacles in the road infrastructure and power and water supply, and have no difficulties in telecommunications. Even the physical environment is considered as a barrier, such as a grant of land use, undefined property rights, the use of the leased premises unstable and short time.

- Reform of governmental administration, it is considered as necessity for governmental administrative reforms by 35 percent of companies. While 37 percent of companies see these reforms as less important, because according to them, they are not effective in this transition phase of Kosovo, due to the same political mentality 
with little substantial difference, so the development opportunities are little. There are 28 percent of companies that did not respond because their opinion does not affect these reforms.

- Removal of unnecessary procedures to the award of licenses is regarded as an important measure to accelerate and improve the environment for doing business in the construction sector. Granting permission for construction is considered as important by 159 companies or 52 percent, as less important is considered by 98 companies or 32 percent, while 50 companies or 16 percent did not respond.

- Further simplification reforms of tax rules and procedures is considered to be done in the way of reducing monthly VAT declarations, and make them quarterly. The removal of cash registers is requested as useless. Electronic declaration of all taxes, job specialization of inspectors to only one field of action, unfamiliarity between inspectors and businesses will become of the annual rotation within the region and within the republic quarterly. Penal procedures to be applied no more than 20 percent of the base tax. Reforms are required by 157 companies or 51.3 percent, not required by 106 companies or 34.6 percent because they consider them less important. No answer was given by 44 companies or 14.1 percent.

- Introducing a strict measure to prevent corruption, the survey estimated (156 companies or 51\%), the introduction of strict measures to prevent corruption is necessary and should be accelerated. 105 companies or 34.3 percent of them consider these measures less important for the implementation because of the weak law implementation, and 46 companies or 14.7 percent did not respond.

- The reform in the educational system, 23\% of the respondents did not answer or 70 companies, whereas reform in the education system (vocational education) to meet the requirements of foreign companies with skilled workers is considered as very important,by 115 foreign companies or 37 percent of them. While, there is little or no consideration for educational reform by 40 percent of respondents.

- Other actions of the government, are considered as necessary to improve the business environment, given the incentives in agriculture 8 percent, lack of law enforcement 8 percent, the protection of copyrights 8 percent, the current customs law 8 percent, tax laws 8 percent, non professionalism 8 percent, removal of complex procedures 8 percent, the informal economy 7 percent, lack of law enforcement in case of trade disputes 7 percent, the implementation of the law 8 percent, putting VAT in same standard scale without changes. By survey is seen that it is necessary to make reforms in all segments of the state, because there is a uniformity of action in Kosovo institutions.

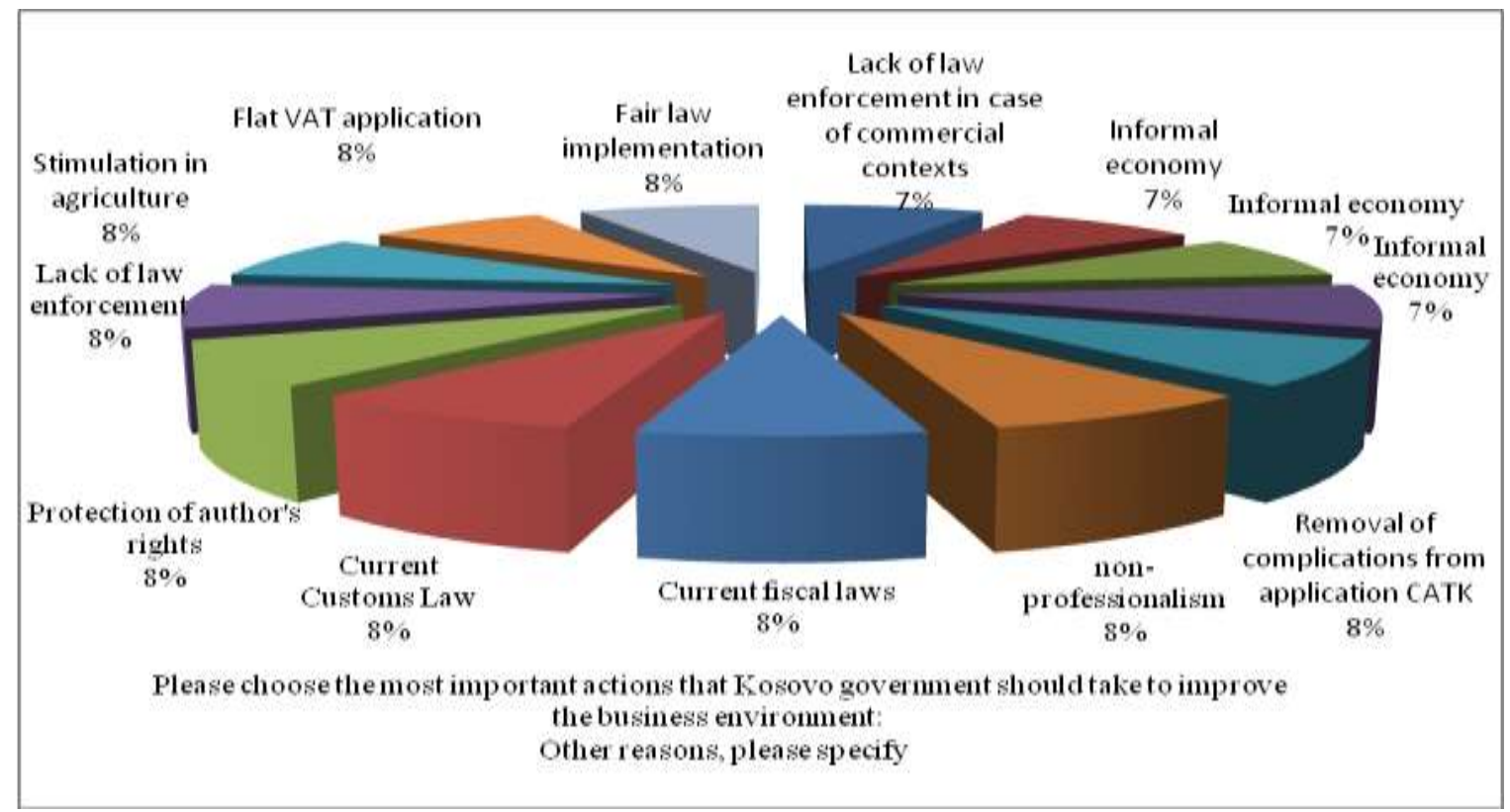

Fig. 5: Other government actions that would contribute to improving the business.

- The first time that has been invested in Kosovo, 37 percent companies responded, while 60 percent of them stated that they had been operating in Kosovo for a long time. There are only 3 percent of companies that did not answer. 
- Information on Kosovo, has mostly been made by friends19 percent, television 19 percent, colleagues 17 percent, family 15 percent, the newspaper 9 percent, Internet 7 percent and by someone else 1 per cent.

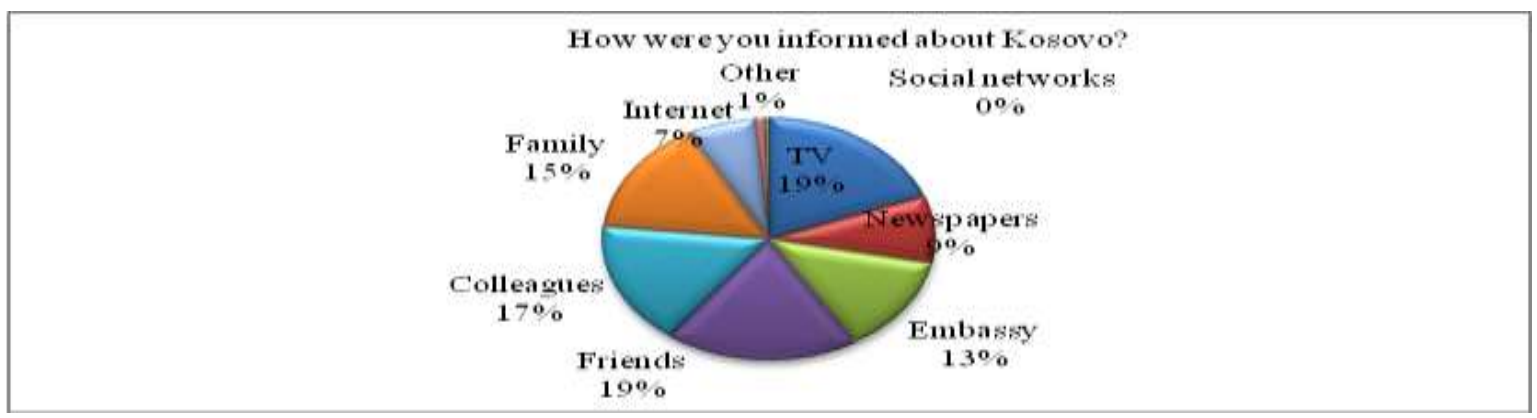

Fig. 6: How were you informed about Kosovo.

\section{Conclusion}

Factors that hinder the flow of FDI in Kosovo are:

Purchasing power is low, low development level of infrastructure, bureaucracy, inefficient legal system, the slow process of the privatization program. These barriers increase the cost of doing business by reducing the profits of investors. Trying to answer the research question, we conclude that FDI does not produce effects in Kosovo. As we can see, the effects depend on the conditions of the host country. In this way, the authorities have a leading role in order to achieve the desired effects through choosing the foreign investment projects that better meet local needs.

- Regardless of the ruling parties the analysis of the past fifteen years shows continuous decreases of FDI trends in Kosovo.

- It was noted that Kosovo has received FDI inflows as a percentage of GDP from $1.5 \%$ in 2004 to $13 \%$ in 2007 and only $5 \%$ in 2013 , the decline continues.

- It was noted that small FDI inflows in Kosovo are found because they are not taken on automatic ways, which would help in eliminating procedural barriers, when the negative barriers appear in society and institutions.

- Infrastructure barriers (roads, railways, airlines, telephone and Internet), have prompted the companies to be directed there where infrastructure is more developed. Rural regions are neglected, remaining underdeveloped (foreign companies mainly operate in the cities of Prishtina, Fushe Kosove, Ferizaj, Prizren and Lipjan), just a few in other places, especially in Dukagjin Area (Peja, Gjakova, Istog, Klina and Deçan).

This has created an influx of population from one city to another, as in the case of the city of Gjakova in every 11 residents, one resident immigrated to the capital - Prishtina (KSA. 2012). This phenomenon has become a trend, regarding the rural areas influencing low development of agriculture, a sector that would affect the economic growth in Kosovo.

\section{The main concerns from existing investors:}

Strengthening of democratic processes, the protection of investors, neglect of municipal and ministerial level, lack of transparency of the tendering procedure, lack of sufficient information by the investment promotion agency IPAK and MTI, bureaucratic procedures, corruption and nepotism.

Also, the unstable political environment, short duration of the leases of buildings, land, contracted works, high penalties by TAK, although there is often forgiveness of debts (by the end of 2015 there are 63 million euro forgiven debt of taxes by TAK through decision of the government), lack of financial incentives, high interest rates in banks (11.1\% in 2013).

\section{Major concerns of potential investors are:}

The infrastructure and physical environment, dysfunctional industrial parks, unstable political environment, frequent changes of law, corruption and nepotism, weak enforcement of law, property disputes, unstable supply of electricity, insufficient supply of water, poor sanitation, uncontrolled distribution of waste, lack of central heating. 


\section{References}

[1] CBK (2015).Quarterly Assessment Report of Economy No. 10, Quarter I/2015.pp.27http://www.bqk-kos.org/

[2] Boric, V. \&Skuflic, L.(2005): "Main determinants of Foreign Direct Investment in theSoutheast European Countries", Euroframe conference on Economic Policy Issues inthe European Union, Transition Studies Review (2006), Institute of Economics, Croatia.

[3] Caves, R. E. (2007). Multinational enterprise and economic analysis (3rd edition), Cambridge University Press, Cambridge. http://dx.doi.org/10.1017/CBO9780511619113

[4] Chowdhury, A. and G. Mavrotas. 2003. FDI and Growth: What Causes What? Paper presented at the WIDER Conference on "Sharing Global Prosperity", WIDER, Helsinki.

[5] Cantwell, J.,Pitelis \& Sugden (2000).A survey of theories of international production, in The Nature of the Transnational Firm, in Nature of the Transnational Firm, London: Routledge. pp 13-17; 20-14.

[6] Coase, R.H. (1937). 'The Nature of the Firm’@@.Economica, New Series, Vol. 4, No. 16.ov., 1937), pp. 386-392. Stable URL:Economicais currently published by The London School of Economics and Political Science. http://links.jstor.org/sici?sici http://dx.doi.org/10.1111/j.1468-0335.1937.tb00002.x

[7] Dunning, J. \& Rugman, A.1985. 'The Influence of Hymer's Dissertation on the Theory of Foreign Direct Investment', American Economic Review, Vol.75, Issue 2, pp228-232.

[8] Demekas, D., Horváth, B., Ribakova, E. \& Yi, W.(2005): “Foreign direct investmentin Southeastern Europe: How (and How much) can policies help?", Working PaperNo.05/110, International Monetary Fund (IMF), European Department.

[9] KIESA (2014). Profili Ekonomik.www.invest-ks.org/sq/Profili-Ekonomik (Economic Profile) http://www.investks.org

[10] MTI (2014) Profili i Sektorit të Industris së Tekstilit.fq.2-36 (Profile of the Textile Industry Sector.pp.2-36) www.mtiks.org / or data; https://ask.rks-gov.net/

[11] Johnson, A.(2005). The effects of FDI inflows on host country economic growth. pp. 3-4.Jönköping International Business School, P.O. Box 1026, SE-551 11, Jönköping, Sweden. E-mail: andreas.johnson@jibs.hj.se 